\title{
MIRRORING MODERNITY: on consumerism in cosmopolitan Zanzibar
}

\author{
Transforming Cultures eJournal, \\ Vol. 4 No 2 November 2009 \\ http://epress.lib.uts.edu.au/journals/TfC
}

\section{Jeremy Prestholdt ${ }^{1}$}

\begin{abstract}
This essay develops an image of nineteenth century Zanzibari consumer sensibilities by demonstrating how goods from and new engagements with distant locales affected the socio-cultural landscape of Zanzibar. The East African port's particular cosmopolitanism represents one form of social reconstitution stimulated by global integration. It also represents a material vision of global relations that was discounted by nineteenth century theorizations of Western modernity. By focusing on the rise of a new materiality in Zanzibar, I excavate precolonial visions of global relations and cultural assimilations of global symbols. I argue that East African desires for goods produced all over the globe represented not simply a Westernization, Indicization, or Arabization of Zanzibar, but also a reconfiguration of a standardized set of global materials in an attempt to bring Zanzibari cultural forms into conversation with broader global trends.
\end{abstract}

[consumerism, globalization, modernity]

The dialectics of nineteenth-century global integration and social change that produced the Western concept of modernity likewise gave rise to new social, cultural, and material realities in the Indian Ocean region. Modernity, as a mode of perception, was ideologically forged at a moment when the world was becoming deeply interconnected. Yet, nineteenthcentury Western analysts tended to discredit other modes of self-perception, material relation, and economic change by theorizing modernity as a bounded temporal form dependent on exclusionary definitions of historical progression and essential difference.

\footnotetext{
1 Jeremy Prestholdt is associate professor of history at the University of California, San Diego. He is the author of Domesticating the World: African Consumerism and the Genealogies of Globalization (2008). His current work addresses violence and the politicization of identity in Kenya. He is also writing on the intersections of politics and consumerism in the appeal of popular icons.
} 
Concurrently, in Zanzibar, East Africa's metropolis, people refashioned their city out of diverse global materials. Excluded from any definition of modernity, change in Zanzibar was as radical as contemporaneous change in Europe. A reconsideration of Zanzibar's nineteenth-century remaking offers an opportunity to revisit the relativism implicit in the idea of modernity and, more importantly, to recognize the new cosmopolitanisms - ways of imagining and acting beyond the local — that were transforming the entire world in the nineteenth century. By focusing on the domestication of imported consumer goods in urban Zanzibar, I will attempt to excavate non-Western visions of globality that mirrored modernity in some ways, but simultaneously cultivated their own singularities. In the sections below, I will focus on the role of new consumer goods in the articulation of changing social relations and global visions from the 1840s to the apogee of Zanzibar's precolonial remaking in the 1880 s.

\section{Modernity and its Relatives}

For nineteenth-century Westerners, the state of being modern entailed a self-conscious alteration of perceptions of time, space, and relation. Modernity was a redefinition of society and theorized as the end of a long historical progression. Because of its comparative nature, modernity found definition on a stage of global interaction through travel, new communication technologies, changing forms of production, consumption, and social as well as political identification. Edward Tylor, one of late nineteenth-century Britain's most celebrated anthropologists, attempted to explain what separated "civilised moderns" from the rest of the world by stressing the crucial role Western knowledge of the world played in the new consciousness. "Acquainted with events and their consequences far and wide over the world," he concluded, "we [moderns] are able to direct our own course with more confidence toward improvement." 2

Modernity was also theorized in dramatic contrast to what Westerners imagined as its opposite. In using the word "modern" its negative, the "primitive", was simultaneously

\footnotetext{
2 Edward Tylor $(1880,1913)$ Anthropology: An Introduction to the Study of Man and Civilization, Reprint, London: D. Appleton and Co.: 439.
} 
defined. ${ }^{3}$ Modernity was like the positive of an image. Though the negative is essential to the creation of the positive, it is at once implied and obscured in the positive's appearance. Thus, Western notions of the modern, civilized, and progressive were given meaning through an implicit reference to the savage, uncivilized, and regressive. ${ }^{4}$ From the eighteenth century, Westerners developed new characteristics of, to borrow Mary Louise Pratt's phrase, a "planetary consciousness" that would provide the foundation for the modern's realization. In effect, new Western subjectivities were formed in direct relation to confrontations with, and images of, others. ${ }^{5}$ In the early nineteenth century, the idea of the "modern" was no longer simply temporal but had become comparative, cultural, and exclusive. Elite ideologues of Anglophone modernity categorized and then ranked populations against the standards of western European upper classes, basing assessments on populations' abilities, objects, and practices, summed up neatly by the words "virtues" and "vices". 6 As taxonomies of humanity became more complex, physicality, materiality, and belief all came into use as numerators in the calculus of civilization.

"Recent work has attempted to challenge these Victorian parameters of modernity by reconceptualizing the modern as no single form, but rather as a diversity of configurations

3 Enrique Dussel (1995) The Invention of the Americas: Eclipse of "the Other" and the Myth of Modernity, New York: Continuum; Enrique Dussel (1997) The Underside of Modernity, ed. \& trans. E. Mendieta, Atlantic Highlands, NJ.

4 Stuart Hall describes modernity's "others" as its "constitutive outside". Stuart Hall and Sarat Maharaj (2001) Modernity and Difference, Annotations 6, London: Institute of International Visual Arts. Susan Friedman offers a particularly rich reading of the history of binary definitions of modernity in (2001) "Definitional Excursions: The Meanings of Modern /Modernity/ Modernism", Modernism/Modernity 8 (3): 503; John Jervis (1999) Transgressing the Modern: Explorations in the Western Experience of Otherness, Oxford: Blackwell.

5 Mary Louise Pratt (1992) Imperial Eyes: Travel Writing and Transculturation, New York: Routledge; see also J. \& J. Comaroff (1997) Of Revelation and Revolution, vol. 2, Chicago: University of Chicago Press; Frederick Cooper \& Laura Stoler (1997) Tensions of Empire: Colonial Cultures in a Bourgeois World, Berkeley: University of California Press; T. Mitchell (2000) "The Stage of Modernity," in Timothy Mitchell (ed.) Questions of Modernity, Minneapolis: University of Minnesota Press; Stuart Hall (1997) "The West and the Rest: Discourse and Power", in Stuart Hall et al. (eds.) Modernity: An Introduction to Modern Societies, Oxford: Blackwell: 184-227; V. Erlmann (1999) Music, Modernity, and the Global Imagination: South Africa and the West, New York: Oxford University Press.

6 Mitchell has summarized this operation succinctly: staging the modern has always required a non-modern. Modernity, he argues, is not possible without those defined against it. Mitchell (2000: xxvi). Where before the English word 'modern' meant simply "contemporary", from the early nineteenth century it began to take on connotations of both time and value: modern was "improved", something which had progressed beyond. Raymond Williams (1976) Keywords: A Vocabulary of Culture and Society, London: Fontana: 174. 
called "alternative", "parallel", or simply "multiple" modernities. Such reconceptualizations of modernity stress heterogeneity in place of the West's singular historical narrative of generation and diffusion, recognizing that modernity was theorized in the West only through a diversity of global encounters. ${ }^{7}$ This body of work has begun to move towards a non-isolationist and multi-causal definition of the modern, and its scope and emphasis on the ramifications of global interconnectivity are invaluable, particularly as a critique of colonial discourse. ${ }^{8}$ To think of modernity in terms of the relationships and nodes of interconnectivity that have affected new permutations in consciousness, as well as their accompanying material forms, disrupts the binary nature of received theories of global history. Moreover, these approaches offer an important challenge to the recent popularization of the "clash of civilizations" rhetorical dichotomization of the world by acknowledging the West's history of interdependence with other world regions. ${ }^{9}$

Such redefinitions must, however, contend with the Manichean connotations that the idea of the modern still maintains. I share an interest in recognizing the importance of diverse global locales in the material and conceptual histories of modernity, but the universal deployment and projection back in time of the term "modern" has the potential to further decontextualize the discursive creation and comparative connotations of the idea that provide its value-laden temporal and cultural comparative basis. In appropriating this particular term of difference and applying it to those it excluded, particularly before colonialism, we run the risk of naturalizing the modern as a global phase of human history instead of a bundle of specific cultural and ideological forms foundational to imperialism and colonization. The idea of "alternative modernities" risks affirming the cultural and temporal singularity Westerners saw as their biological virtue, posing other visions as

7 See Mitchell (2000); Carol A. Breckenridge (1995) (ed.) Consuming Modernity: Public Culture in a South Asian World, Minneapolis: University of Minnesota Press.

8 Sanjay Subrahmanyam (1998) "Hearing Voices: Vignettes of Early Modernity in South Asia, 1400-1750", Daedalus 127 (3): 75-104. See also "Special Issue: Alter/Native Modernities", Public Culture, 11 (1), especially L. Lee (1999) "Shanghai Modern: Reflections on Urban Culture in China in the 1930s", Public Culture 11 (1): 75-108; (2000) "Special Issue: Multiple Modernities", Daedalus 129 (1), especially N. Göle (2000) "Snapshots of Islamic Modernities": 91-115; M. Featherstone et al. (1995) (eds.) Global Modernities, London: Sage. 
divergence from the (Western) norm, and reifying the Victorian notion of time as progressing in an evolutionary order. ${ }^{10}$ Following Arif Dirlik's critique of the naturalization of capitalism in world-system, neo-liberal, and postcolonial historiography, the universalization of modernity has the potential to obscure the historical desires of those who did not share Western visions of globality by allowing only "multiple modernities", not divergent, though interconnected, strategies of global relation. ${ }^{11}$

Precolonial Zanzibar offers an illuminating example of the conceptual differences between Western modernity and a connected, nineteenth-century cosmopolitanism. Zanzibari perceptions were informed by engagements with other parts of the world, but did not entail an acceptance of the ideologies of the West, such as Western science, liberal democracy, and the notion of the past as an evolutionary course. Very few East Africans shared Western bourgeois assumptions of historical progress and political culture, even though they incorporated a diversity of Western goods and technologies into their everyday lives. For instance, Zanzibaris incorporated European and American clocks into the cityscape, but did not regulate their day by the clocks' movement. Changes in Zanzibari material life, therefore, mirrored changes in the West, but Zanzibaris did not share the basic conceptual underpinnings of Western modernity. Only under colonialism would Zanzibaris adopt certain assumptions about political culture, social norms, and historical teleology drawn from Western modernity.

9 On the continuance of Victorian dichotomies in contemporary thinking even before 9/11, see Edward Said (1999) Covering Islam, New York: Vantage.

10 John Comaroff (2002) “Governmentality, Materality, Legality, Modernity," in Jan Georg Deutsch, Peter Probst \& Heike Schmidt (eds.) African Modernities, Portsmouth: Heinemann: 130, fn. 40. Dirlik draws a similar critique of Gunder Frank's five thousand year world-system. By universalizing capitalist development, Gunder Frank poses it as the fate of humankind rather than the product of a specific history, Arif Dirlik (1999)"Is there History After Eurocentrism: Globalism, Postcolonialism, and the Disavowal of History", Cultural Critique 42: 15. Mitchell is perhaps the most direct in his assessment. For him, the vocabulary of "alternative modernities" reinforces a fundamentally singular modernity, only modified by certain local circumstances, Mitchell (2000: xiii).

11 Dirlik (1999: 15); Jan Georg Deutsch, Peter Probst \& Heike Schmidt (2002) "Cherished Visions and Entangled Meanings", in Deutsch, Probst \& Schmidt (2002: 1-17). 
As opposed to an "alternative" modernity, Zanzibar's unique remaking was a form of cosmopolitanism typified by what Homi Bhabha, Carol Breckenridge, and Dipesh Chakrabarty summarize as the ability to see, "the larger picture [of the world] stereoscopically with the smaller". ${ }^{12}$ If cosmopolitanism implies an ability to think and act beyond the local, Zanzibari cosmopolitanism represented one way of incorporating the symbols of myriad places without importing the values of those places. Zanzibari bricolage grew out of impressions and first-hand experiences of the world through global travel, trade, and access to information flows. Thus, Zanzibar's cosmopolitanism was a particular vision of the world that referenced trans-oceanic trends but made them relevant to the Zanzibari social environment, much as the notion of modernity did for Western analysts. Zanzibar mirrored modernity: it superficially reflected aspects of contemporaneous Western societies, but engaged in a process of change with its own logics and repercussions.

\section{Objects of Cosmopolitan Zanzibar}

In April of 1840, the Sultan of Zanzibar's bark, the Sultana, arrived in New York. It was the first vessel of either an African or Arabian state to travel to America, and it carried the first Arab emissary to visit the United States. Yet, the Sultana's diplomatic mission was secondary. The envoys would never visit Washington, DC. Instead, the Sultana sailed to America's commercial heart. Accordingly, the envoys doubled as traders, buyers of American consumer goods and sellers of western Indian Ocean products. The crew was representative of Zanzibar's maritime culture, made up of enslaved Africans, Indian sailors from across the sub-continent, an Arab-Swahili diplomatic party, a Portuguese (probably Goan) cook, a Swahili captain, an English navigator, two French passengers, and two Englishwomen. The chief envoy, al Hajj Ahmad bin Na'aman bin Mushin bin Abdulla el Kaabi el Bahrani, Secretary to Sultan Seyyid Said, boasted a career equally emblematic of the new Zanzibar. Born in the Persian Gulf, he took up residence in Zanzibar, made the

12 Carol Breckenridge, S. Pollock, Homi Bhabha \& Dipesh Chakrabarty (2002) "Cosmopolitanisms", in Carol Breckenridge, S. Pollock, Homi Bhabha \& Dipesh Chakrabarty (eds.) Cosmopolitanism, Durham: Duke University Press: 11. 
hajj, and in the service of Seyyid Said traveled to Europe and America as well as to Cairo and Canton.

The Sultana's voyage to New York was, much like later Zanzibari missions to England and France, an experiment. The sultan had always employed ships in the India trade. He even talked of sending vessels to Manila in order to procure sugar. ${ }^{13}$ But direct trade with the West had to this point largely been in the hands of Westerners. Seyyid Said attempted to change this. In the years that followed the Sultana's voyage, Seyyid Said would send several vessels to London and Marseilles - one with a cargo totaling 100,000 Maria Theresa thalers, or about twice that of the average cargo leaving Zanzibar on a European vessel — and these would return with an assortment of consumer goods for local sale. ${ }^{14}$ In New York, the sultan's agents purchased an assortment of American consumer goods and, in accordance with Zanzibar's 1833 commercial treaty with the United States, were given most favored nation treatment. ${ }^{15}$ The Sultana arrived in New York laden with the western Indian Ocean's export mainstays: cloves, gum copal, coffee, ivory, dates, hides, and Persian carpets. ${ }^{16}$ The return cargo included:

8004 large "china plates"

550 yards of red joho [broadcloth used for the making of overcoats, or joho] 2 boxes of red beads

4 barrels and one box of white beads, some additional blue beads

20 dozen boxes of gold leaf or leaf metal, each leaf measuring $16 \times 15$ in.

125 bales [88,101 yards] of American cloth, or merekani. ${ }^{17}$

13 Zanzibar imported several tons of sugar every year from the U.S., France, India, and Singapore, both in loaf and refined granule form. See, for example, Rigby, "Return of the Imports at the Port of Zanzibar for the Year 1859", Zanzibar National Archives (hereafter ZNA) AA2/4. On the Manila project, see Drinker in H. Eilts (1962)“Ahmad bin Na'aman's Mission to the United States in 1840, The Voyage of Al-Sultanah to New York City”, Essex Institute Historical Collections 98 (Oct.): 272.

14 Ward to Buchanan, 13 March 1847, United States Consulate, Zanzibar (hereafter USCZ), Roll 1, Vols 1-3. American and European merchants alike in Zanzibar developed a "deep concern" about the Sultan's mercantile pursuits, particularly his direct trade with the West, since he imported all goods duty free. Peters and Pollock to Sultan Sayyid Said, 20 February 1847, ZNA AA1/3; Hamerton to [obscure], 3 January 1847, ZNA AA1/3.

15 Eilts (1962: 271).

16 A. Jiddawi (1951) "Extracts from an Arab Account Book, 1840-1854," Tanganyika Notes and Records 31: 27.

17 Jiddawi (1951: 29). 
300 muskets and powder

Such a manifest was typical of Zanzibar's import trade at mid-century and reflected the consumer tastes of a broad cross-section of East Africans: plates, gold leaf, and red broadcloth for ornamental and adornment purposes in Zanzibar, beads and American cloth (called merekani in Swahili) for Zanzibari and mainland consumption, and firearms and powder for sale across the region. In addition to selling commodities on behalf of the sultan, Ahmad bin Na'aman was commissioned to search out special consumer objects, such as chandeliers, cases of pineapple and orange syrup, confectionery almonds, glass plates, watches, shotguns, lamps, and mirrors, for some of Zanzibar's wealthiest residents. ${ }^{18}$ What is so important about this manifest, and the manifests of most ships which traded at Zanzibar, is that only a very small proportion of the objects listed could be considered utilitarian. The staples of the East African import trade, things like the countless varieties of cloth, beads, brass wire, and home furnishings, were not the stuff of everyday productive activities, as were hoes or rope. The goods that would make up the vast majority of East African imports were objects destined for the social realm of display and public communication.

By the 1850s, the entirety of the East African economic system, not just the emporium of Zanzibar, was increasingly driven by the demand for imports. Over the course of the century, the consumption of imported goods would increase tenfold, and Zanzibari social relations would become dependent on diverse commodities as important means of communication in the public realm: a phenomenon we might for convenience call consumerism. ${ }^{19}$ So key had certain consumer goods become to Zanzibari merchants and consumers that dictums like, "it is always far more easy to dispose of a cargo at Zanzibar

\footnotetext{
18 Eilts (1962: 252); Jiddawi (1951: 29); Letter from William H. Feely, 14 March 1845, PE MH-14, Richard P. Waters Papers.

19 For recent definitions of consumerism in varying contexts see C. Carson (1994) "The Consumer Revolution in Colonial British America: Why Demand?" in C. Carson et al. (eds.) Of Consuming Interests: The Style of Life in the Eighteenth Century, Charlottesville: University of Virginia: 486, fn. 5; Peter Stearns (2001) Consumerism in World History: The Global Transformation of Desire, Routledge: New York: ix.
} 
than to procure one", appeared regularly in the correspondences of Western residents. ${ }^{20}$ Zanzibari consumerism was a new engagement with global cultural flows, a deployment of global symbols in the service of local image-making practices, or what Jean and John Comaroff have summed up as incorporating diverse ways of seeing and being without negating one's own. ${ }^{21}$ This consumer culture was also deeply interwoven with new perspectives on the world gained through travel and the circulation of information. In the early part of the nineteenth century foreign vessels trading in Zanzibar were generally based in ports within the western Indian Ocean region, and to a lesser extent the US, Marseilles, and Hamburg. But by the 1860s, vessels from all over the world visited Zanzibar. The American Consul wrote in the mid-1860s of not only Indian, Arab, American, French, and Hanseatic vessels, but also of Portuguese, Egyptian, Danish, Sardinian, Hanoverian, Turkish, British, Italian, Spanish, and even Argentine merchant ships in port.

Zanzibaris travelled as widely as their economic connections, and thus the new economy of East Africa directly affected the cultural landscape of Zanzibar. Take, for instance, the case of Rajab, a well traveled, English-speaking Zanzibari featured in H. Ross Browne's popular account of Zanzibar in the early 1840s. His time in Zanzibar drawing to a close, Browne, an American sailor and travel writer, began searching for representational curiosities to take home. An acquaintance of his, Rajab, who had spent some time in New England employed as the groom of Arabian horses, agreed to conduct Browne through the town in search of the desired goods: shells and a spear. ${ }^{22}$ After purchasing the shells, Rajab mentioned that a neighbor of his had a very handsome spear and, if Browne accompanied him home, he would try to get it. Rajab's house, though in the "dirtiest part of town", according to Browne, was whitewashed and "neat". Written on the door were the words: "Rajab No.1". On entering the front room, Browne was "quite struck with the neatness and taste with

\footnotetext{
20 Rigby to Wood, 1 May 1860, India Office Library, British Library (hereafter IOL) L/P\&S/9/37.

21 Comaroff (1997: vol. 2: 89).

22 This kind of transatlantic travel was common in the early to mid-nineteenth century. For example, American merchant ships often employed Zanzibaris and Comorians for multiple journeys. See, for example, the contracts of 'Malbruke, Hammadee, \& Oulede,' to work on the bark Arthur Pickering in Consular Certificate, Mansfield, 14 December 1858, PE MH 23 West Papers.
} 
which it was furnished. A rich carpet, a polished table, and the usual number of chairs, looking-glasses, \&c., which make up the furniture of a snug Western log-cabin". To Browne, these "evince[d] something of the civilized notions which Rajab had acquired in Salem [Massachusetts]". Rajab entertained his guest with stories of his experiences in America, of steamships and locomotives, of Salem and the curiosities of Boston. Rajab compared the houses in Salem and Boston to those of Bombay and Zanzibar. He boasted that a certain Mr. Sheppard ${ }^{23}$ even painted his portrait during his stay and gave it to him as a gift. However, on Rajab's return, his mother was enraged by the image and denounced the artist, according to Browne, as a dealer in "evil sciences", adding that Rajab could only regain "the lost flesh, and whatever of his soul he had lost with it, by destroying the painting". This she forced him to do, Browne wrote, "much to his mortification". 24

Browne's vignette and Rajab's experiences are instructive on two accounts. First, Browne's description highlights the role of consumer goods - particularly Western manufactures - as important new cultural technologies in Zanzibar. Rajab's eagerness to tell of his experiences, demonstrate his taste in furnishings, and prove his command of English to his neighbours and guests represents a mode of what we might term cultural domestication, in which bold incorporations of foreign things were possible and accretions of globality offered valuable social leverage. The second insight the story yields is the way in which, beginning in the 1840 s, not only were Zanzibaris drawing more deeply on material culture from America, Europe, and India, but Western authors were becoming more keenly focused on consumer objects as criteria for typologizing Zanzibaris.

Through the vehicles of imported and stylistically-remade goods, Zanzibaris were creating a symbolic logic of culturedness which at times accorded with the sensibilities of foreign commentators; that Browne was enamoured of Rajab's furnishings, even likened their configuration to American homes (if somewhat mockingly), suggests a Zanzibari

\footnotetext{
23 Possibly Michael Sheppard, a Salem businessman whose firm had agents at Zanzibar, or a member of his family.

24 H. Ross Browne $(1846,1968)$ Etchings of a Whaling Cruise, reprint, Cambridge, MA: Belknap Press: 4123,345 .
} 
familiarity with trans-cultural domestic signifiers. Yet, despite Rajab's communicative abilities, Browne's denouement, placed as it is immediately following a suggestion of Rajab's civility, privileges myths of African/Oriental aversion to change, a vein of analysis that would be canonized in later analyses of Zanzibaris as prisoners of their static past.

Nonetheless, it would be wrong to assume that Rajab's mother's condemnation of the portrait was a rejection of symbols, goods, and technologies from abroad. In fact, not only was her house full of American objects, but soon after Browne's arrival she appealed to him for medical assistance. Moreover, such apprehension about portraiture was becoming increasingly rare in Zanzibar. Though some Zanzibaris thought them un-Islamic, portraits were gaining popularity. Seyyid Said, his sons, and his ambassador Ahmad bin Na'aman all sat for portraits about the same time Rajab was forced to torch his likeness. Even photography was well known at mid-century. Immediately after Browne's departure, Guillain, a French captain and Orientalist, took an extensive series of daguerreotypes of Zanzibaris that crossed status and gender lines and included many of Zanzibar's political elite. $^{25}$

By the 1860 s, paintings, printed illustrations, and photographs were all fashionable in Zanzibar. While in Zanzibar, Clelia Weeks visited a woman described simply as "Bibi Aisha" who showed her a full-length oil painting of Sultan Majid, and "drew forth from a recess several other portraits of former Sultans [probably relatives of the sultan, not his predecessors]". Bibi Aisha then took her to another room containing more pictures, including one of Ali Pasha and his wife from the London Illustrated News, portraits of Queen Victoria, Franz Joseph and his wife, "besides an oil-print just published of a girl in pink seated on a window-ledge kissing a love-bird". ${ }^{26}$ Rebecca Wakefield wrote of her visit to Ali bin Suleiman's house where she, "inspected...albums; in which were some of the most splendid cartes I ever saw; chiefly of the sovereigns of Europe, and their families", as

25 M. Guillain (1856) Documents sur l'histoire, la géographie et le commerce de l'Afrique Orientale, illustrated volume, Paris: Bertrand. By 1891, the sultan was handing out autographed photographs to visitors. See M. French-Sheldon (1892) Sultan to Sultan: Adventures among the Masai and other Tribes of East Africa, London: Saxon \& Co.

26 Clelia Weeks (1868-69) “Zanzibar”, Harper's New Monthly Magazine 38 (Dec.-May): 313. 
well as stereographs, piles of which were spread across the table. ${ }^{27}$ Images, particularly of distant rulers and panoramic scenes, were by mid-century some of the most vivid examples of what Homi Bhabha termed "certain symbols of the elsewhere" that contributed to Zanzibar's new global consciousness. ${ }^{28}$

Pictures were one component of a larger symbolic system. They were only given importance and sign-value through their place in a standard assortment of domestic consumer objects. To take the reception room as an example, the creolized assortment of consumer goods found in a moderately wealthy Zanzibari's home at mid-century included: Persian rugs; Chinese pillows; Indian, European, and American tables; American, Indian, European, and Chinese chairs; French mirrors; pictures; American and European clocks; and Asian as well as European porcelain. ${ }^{29}$ Wakefield visited the home of an enslaved pilot only identified as "Bukhett" where she found his stateroom full of a variety of familiar "ornaments", including vases, glassware, china, pictures, and mirrors. ${ }^{30}$ Sayyida Salme binti Said, one of the only Zanzibaris of the time to write an account of the city for Western audiences, described wealthy people's homes as having all the above accouterments, adding that in wall recesses, "the choicest and most expensive objects of glass and china are symmetrically arranged...A handsomely cut glass, a beautiful painted plate, an elegant jug may cost any price: if it only looks pretty, it is sure to be purchased". Between these recesses a family might place mirrors, "expressly ordered from Europe", reaching from floor to ceiling. She added that, "of late...[pictures] are tolerated". Clocks, she continued, were particularly desirable items of interior decor and "often the richest collection is found in one single house". These were juxtaposed with the mirrors, either placed in front of them so that the clocks were reproduced in the reflection or on either side so that they highlighted the mirrors. Finally, Salme writes, the walls of men's rooms were decorated with

27 Rebecca Wakefield (1879) Memoirs of Mrs. Rebecca Wakefield, Wife of the Rev. T. Wakefield, (ed.) R. Brewin, London: Hamilton, Adams, \& Co.: 112-13.

28 Homi Bhabha in a question addressed to James Clifford in Lawrence Grossberg, Cary Nelson, and Paula A. Treichler (eds.) (1992) Cultural Studies, New York: Routledge: 114.

29 J. Osgood (1854) Notes of Travel or Recollections, Salem: George Creamer: 29-30; Judy Aldrick (1997) "The Painted Plates of Zanzibar", Kenya Past and Present 12: 26-8.

30 Wakefield (1879: 93-4), 108; Weeks (1868-69: 307. 
"trophies": inlaid and expensive weaponry from Persia, Turkey, Arabia, Europe, and the US. ${ }^{31}$

Objects acted in concert to signify the new urban culturedness of Zanzibar. Nineteenthcentury descriptions of Zanzibar interior design evidence what cultural theorist Jean Baudrillard calls the object system of consumer societies. By using the word "system" Baudrillard suggests that individual objects do not function on their own but instead depend on a system that relates the larger meaning of the whole. In this logic, consumer objects can be incorporated as signs entirely divorced from the function intended by their manufacturers. Consumer choices need not respond to the demands of comfort or function as long as they address a social logic in which specific objects are desired for their abilities to contribute to a conglomerate social meaning. ${ }^{32}$ While a porcelain vase by itself might have been interpreted in infinite ways depending on context, its placement with clocks, mirrors, and chairs shaped it into a reflection of cultural refinement. ${ }^{33}$

In Zanzibar, even the most seemingly functional object was at times valued for its sign qualities. Sayyida Salme described her father's enormous collection of European furniture as including sofas, chairs, tables, even a wardrobe, that served "more as show-pieces than for real use". ${ }^{34}$ Elizabeth Jacob wrote of the European carved chairs and bedsteads in one of her host's reception rooms, but added that she was told these were never used. ${ }^{35}$ The European (or Indo-European) chair even became a poetic metaphor for material luxury in

31 Emily Ruete [Sayyida Salme] (1993) Memoirs of an Arabian Princess, in E. Van Donzel (ed.) An Arabian Princess between Two Worlds: Memoirs, Letters Home, Sequels to the Memoirs, Syrian Customs and Usages, New York: E.J. Brill: 164-65.

32 Jean Baudrillard (1988) Jean Baudrillard: Selected Writings, (ed.) Mark Poster, Palo Alto: Stanford University Press: 44.

33 The consumer's "need" for the vase is often directly related to its essential place within a standard assortment of goods. We can think of contemporary American homes in similar terms. A "complete set" for the living room often includes a couch or sofa, easy chair, television, coffee table, entertainment center, bookcase, and pictures on the wall. The absence of any one of these can seem disorienting and thus each is desired for its importance to the completion of the culturally defined set.

34 Baudrillard (1988: 196).

35 Elizabeth and Henry Jacob (2000) A Quaker Family in India and Zanzibar, 1863-1865, (ed.) Y. Bird, York: Ebor Press: 165. 
nineteenth-century Swahili verse, a meaning quite divorced from the chair as an instrument of physical comfort. ${ }^{36}$

\section{Place and Motion}

As the examples of Rajab and "Bukhett" suggest, the new cultural-material codes of Zanzibari social relations were born of Zanzibari travel to, experience, and imagination of various global locales. Zanzibari consumerism was in a constant dialectic with cultural trends in Muscat, Bombay, Paris, New York, and London. When Richard Waters, the American Consul in Zanzibar, first moved into his residence, he was entirely unprepared for the attention the house received. He wrote that people were continually calling at the consulate out of curiosity to see it, "made up", as it was, "in an American fashion". 37 A few years later, Browne, along with several other American residents, was invited to the shamba [Swahili: plantation, farm, or country estate] of "Hadji Mouchad" to celebrate the anniversary of the Battle of Bunker Hill. When they were called to dinner they found a long table set in the middle of the room with a white cloth, knives, plates, and spoons all arranged, "as near in the American style as could have been expected from an Arab". After dinner came dessert and coffee, and "Mouchad" entertained the group with a narrative of his journey to Mecca. "When he...concluded", Browne wrote, "we had several patriotic sentiments in commemoration of the battle of Bunker's Hill". 38

Elizabeth Jacobs wrote of a similar experience. She was invited to the house of Bibi Suleiman, a relative of Sultan Majid's who, after entertaining, brought in English coffee, "or what she called 'English' in great glee — that is, coffee with milk and sugar and also in English cups". 39 An American described the accomplished captain Hassan bin Ibrahim's house as furnished with Windsor chairs, a table, a bureau, an American clock, and several English prints of rural scenes. But the visitor was particularly impressed when Hassan

\footnotetext{
36 Edward Steere (1872) “On East African Tribes and Languages," Journal of the Anthropological Institute of Great Britain and Ireland 1: cxlvi.

37 Waters Journal, 14 April 1837, PE MH 14 Richard P. Waters Papers.

38 Ross Browne (1846, 1968: 441).

39 Jacob (2000: 165).
} 
welcomed him into his receiving room with offers of brandy and wine. ${ }^{40}$ Born in Muscat, Hassan had studied in Bombay and Calcutta, made several voyages to Canton, Mauritius, and between the Gulf and East Africa, spoke English with "but little accent", and thoroughly understood Western codes of civility. Hassan had traveled the world, seen diverse elsewheres, and materially evoked these at home. ${ }^{41}$ These anecdotes suggest two related trends: the phenomenon of culture constituted through travel and time-space compression-what Jim Clifford calls "travelling culture"-and place-specific cultural trends constituted in the collection of filtered and creolized global flows. ${ }^{42}$ At times hardly differentiable, and always closely related, these trends were the product of activities by people of diverse social categories.

Though I have perhaps not made the point forcefully enough, travelling cultures affected and were effected by Zanzibaris of all socioeconomic position, not simply captains or diplomatic envoys. For example, most Zanzibari travelers to Arabia, India, Europe, and within the East African region were not elites. Sailors, small business people, and slaves of all variety constituted the vast majority of Zanzibar's travelling culture. ${ }^{43}$ A glance at the English consulate records of freed slave sailors and travelers reveals that hundreds of Zanzibari contract workers were travelling to Arabia, India, and elsewhere in any given

40 On Captain Hassan, see Captain Henry Hart to the Vice Admiral Sir John Gore, 10 February 1834, IOL F/4/1475, Board's Collections vol. 1475; W. A. Ruschenberger (1839) A Voyage Round the World: Including an Embassy to Muscat and Siam, in 1835, 1836, and 1837, Philadelphia, PA: Carey, Lea \& Blanchard: 37.

41 Ruschenberger (1839: 28-9).

42 James Clifford (1997) Routes: Travel and Translation in the Late Twentieth Century, Cambridge: Harvard University Press; Ulf Hannerz (1987) “The World in Creolization”, Africa 57: 546-59.

43 See, for instance, the story of Juma Nasibu, one of the porters in Dodgshun's caravan to Ujiji in 1877-79, who had been in England for three years where he had spent several months in school. He used this experience to his advantage and found employment with the Cameron expedition and later worked at the British consulate. Norman Bennett (ed.) (1969) From Zanzibar to Ujiji, The Journal of Arthur W. Dodgshun, 1877-1879, Boston: Boston University: 35, 55 fn.113. Charles Pickering wrote that he met many "Soahili" in Bombay who came to India as free sailors; Charles Pickering (1876) The Races of Man and their Geographical Distribution (London: George Bell and Sons: 192. See also Sultan Majid's protest of the constant English harassment of Zanzibari shipping under the pretence that the African crews must be slaves; Saeed bin Majid to Chuchill, December 1868, IOL L/P\&S/9/48; and "Return of Slaves emancipated by Lieut. Col. Playfair, from the date of his assuming charge of British Consulate Zanzibar [n.d.]," ZNA A12/3. 
year, and a sizable proportion of them were women. ${ }^{44}$ Slaves, according to British Consul John Kirk, were, "sufficiently free to go [more precisely, to be sent] to India and return to Zanzibar". 45 Such people often relied heavily on their experiences abroad for the negotiation of their public image in Zanzibar.

One such cosmopolitan - the leader of the Teleki expedition across what is now Kenyawas "Qualla Idris", a Somali who by the age of twenty-four had spent time in America, been with the Stanley expedition in Central Africa for six years, traveled with Stanley in Europe, and spoke Swahili, Somali, Arabic, Hindi, and English. ${ }^{46}$ Browne wrote that many young Zanzibaris studied at European colleges and seminaries, and that these educational experiences were "a matter of pride", having the effect of causing other Zanzibaris to consider them "persons of consequence". 47 Jacob Wainwright, a freed slave assistant to David Livingstone and convert to Christianity, travelled extensively in Eastern Africa, studied in England and Bombay, and was the first East African to publish a journal of his caravan experiences. ${ }^{48}$ After returning to Zanzibar from his sojourn in England, he was hired by English missionaries on the mainland. Soon thereafter he was dismissed. According to the travel-writer Joseph Thomson, Wainwright was "in the habit of twitting his European masters with the fact that they had never, like him, had the honour of being presented to her Majesty Queen Victoria". ${ }^{49}$ In this case, Wainwright employed the British fetish of Queen Victoria as leverage in his relationship with his employers.

44 Ship's Register, British Consulate: Free African Register, ZNA AA12/13; Janet Ewald (2000) "Crossers of the Sea: Slaves, Freedmen, and other Migrants in the Northwestern Indian Ocean, c. 1750-1914", American Historical Review 105 (1): 69-91.

45 Kirk to Secretary of the India Office, 23 April 1869, IOL L/P\&S/9/48.

46 L. von Höhnel (1894) Discovery of Lakes Rudolf and Stefanie, Vol. 1, London: Longmans, Green, and Co.: 11-12.

47 Ross Browne (1846, 1968: 350).

48 For Wainwright's journal see “Tagebuch von Jacob Wainwright über den Transport von Dr. Livingston's Leiche, 4 Mai 1873-18, Februar 1874," Petermann's Mittheilungen 20 (1874).

49 Joseph Thomson (1881) To the Central African Lakes and Back: The Narrative of the Royal Geographical Society's East Central African Expedition, 1878-80, London: 34. Hugh Peter Kayamba, son of Sultan Kimweri of Wakilindi, likewise studied in England before returning to Zanzibar to teach at St. Andrew's College (UMCA). Kayamba was a Muslim, but converted to Christianity and studied at UMCA schools 
The missionaries' response was predictable: a dismissal of Zanzibari self-making as patently out-of-place and disrespectful. Wainwright's story reveals both the experience of Zanzibaris in a globalizing moment and the increasing permeability of status in Zanzibar. The life of Muhammad bin Khamis bears further testimony to this. Son of Khamisi wa Tini-who was described as "Sawahili" — "he has certainly something to boast of", Browne wrote, juxtaposing a racial taxonomy with the actuality of ability, "for, although as black as the ace of spades... and of low descent, he got himself into notice by his own natural talent and his perseverance". Browne was "greatly amused" both to hear of Muhammad's travels, having, "on various occasions, dined with the queen [of England]", and by the "tone of familiar freedom with which he alluded to his friends Lord - , the Duke of - , Sir Thomas or Sir John —, \&c". ${ }^{50}$ While in England, Muhammad even approached the Royal Geographical Society with his own proposal for the exploration of the lakes region of East Africa. Though certainly more qualified than Richard Burton, who would later lead such an expedition, the Society did not select Muhammad as a member of its exploratory parties. He was too incongruous with the image of the explorer as a shining icon of Victorian masculinity. 51

People like Muhammad bin Khamis were essential to the constitution of Zanzibar as a "travelling culture", and their ubiquity makes my second point - the role of people who did not travel in forging new cultural forms-more difficult to address. The vast majority of Zanzibar's residents had experienced significant dislocation. At mid-century more than half of Zanzibar city's population were slaves or freed slaves, and it seems likely that most enslaved Zanzibaris were born on the African mainland. In addition to the enslaved

before travelling to England. M. Kayamba (1936) "The Story of Martin Kayamba Mdumi, M.B.E. of the Bondei Tribe," in Marjory Perham (ed.) Ten Africans, London: Faber and Faber.

50 Muhammad bin Khamis accompanied the sultan's envoy to England in 1842 and had been previously "taken to England to be educated" by one Mr. Hunt. Hamerton to Secret Committee, 9 February 1842, IOL $\mathrm{L} / \mathrm{P} \& \mathrm{~S} / 9 / 12$. The renowned geographer William Cooley depended on Muhammad bin Khamis' information for his Inner Africa Laid Open, in an attempt to trace the chief lines of communication across that continent south of the equator (London: Longman, Brown, Green, and Longmans, 1852). Ross Browne (1846, 1968: 344-45); cf. J. Osgood (1854: 45); Richard Burton (1872) Zanzibar: City, Island, and Coast, Vol. 1, London: Tinsley Brothers: 286.

51 Burton later wrote of Muhammad's proposal and dismissed it as if the very prospect were richly ironic. Burton (1872: vol.2, 287). 
population, Zanzibar absorbed immigrant groups from southern Arabia, India, the Comoros, and Madagascar. In fact, most of the residents of the city had experienced significant change in their cultural environments. While not everyone in Zanzibar was mobile, the experiences of those who travelled affected those who did not. For example, an American in Zanzibar wrote of a young man who had learned English from his father. ${ }^{52}$ Such instances of creolization in stasis abound, particularly when we move from the linguistic to the material realm. This suggests not a dissonance between two distinct cultural experiences - travel vs. stasis—but their inextricable relation. ${ }^{53}$

In the rapid acceleration of interconnectivity fueled by travel, forced migration, trade, and a polyglot population, a dynamic nexus of creole consumerism took shape in Zanzibar. Though it might be easy to relegate Zanzibari interest in foreign objects to a fetish of other cultures, such an analysis quickly arrives at an impasse, leading us to the conclusion of most nineteenth-century analysts: Zanzibaris were simply obsessed with manufactured goods. ${ }^{54}$ What seems a more lucrative analytical strategy is to think of consumerism as, following Clifford, a way of localizing "symbols of the elsewhere" for purposes of specific action. Of course, desire and symbolic function need not, indeed should not, be separated. 55 Their integration in Zanzibar's tumultuous social environment of marginal indigeneity became what Caroline Humphrey has neatly termed, a "key means of creating value'.56

52 Ruschenberger (1839: 37).

53 Even new pepo (spirits) came into existence. Grant wrote that the Zanzibari freed slaves in his employ described a great variety of pepo, including several of English and Ethiopian provenance. James Grant (1864) A Walk Across Africa, or Domestic Scenes from My Nile Journey, Edinburgh: William Blackwood \& Sons: 259. Alpers has analyzed a mid-nineteenth century pepo of which a detailed description exists. Gongoni binti Gongoni was a female pepo whose genealogy linked her to Pemba, Tumbatu, and southern Arabia. Edward Alpers (1984) “'Ordinary Household Chores': Ritual and Power in a 19th-Century Swahili Women's Spirit Possession Cult", International Journal of African Historical Studies 17 (4): 695.

54 See Anne McClintock (1995) Imperial Leather: Race, Gender and Sexuality in the Colonial Conquest, New York: Routledge, and T. Richards (1990) The Commodity Culture of Victorian England: Advertising and Spectacle, 1851-1914, Palo Alto: Stanford University Press.

55 James Clifford (1992) "Traveling Cultures," in Lawrence Grossberg, Carrie Nelson \& Paula Treichler (eds.) Cultural Studies, New York: Routledge: 96-116 (114-5).

56 Caroline Humphery (1995) "Creating a Culture of Disillusionment: Consumption in Moscow, a chronicle of changing times," in Daniel Miller (ed.) Worlds Apart: Modernity through the prism of the local, New York: Routledge. 
Wealth, master-slave relationships, and gender relations functioned as social barriers, but Zanzibaris of all backgrounds found themselves on two common planes of interaction: (1) language, or the use of Swahili as a lingua franca, ${ }^{57}$ and (2) consumerism, or an emphasis on objects to communicate social ideas. Consumer goods such as mirrors, watches, jewelry, porcelain, and clothes proved communication devices as important as the spoken word. Consumerism became a catalyst for sociocultural grounding, a strategy for representing the self in the diversity and movement of Zanzibar's population. In the transience of nineteenth-century Zanzibar, consumerism created a relatively grounded mode of social communication. Freedmen, for example, appropriated the kanzu (long shirt made of imported cloth) to mark local affiliation and a transcendence of slavery. In their appropriation of the kanzu, freedmen laid claim to Zanzibar's creole cultural forms. Imported cloth, when fashioned into kanzus, was a vehicle for the relocation and grounding of identity; it signified a cultural elsewhere distinct from freed slaves' home societies and a social elsewhere distinct from slavery.

Due to the rapid expansion of Zanzibar's economy in the early nineteenth century, and its political dominance by immigrant BuSaidis, "patina"- - a mode of social relation anchored to notions of historical distinction, such as existed in Lamu and Pate-was in many ways undermined by "fashion": a mode of social relation relatively unbound from historical restrictions such as sumptuary regulations. ${ }^{58}$ The increasing volume and diversity of consumer goods offered new modes of self-expression largely unfettered by prerequisite genealogies or long histories of residence in the coastal region. ${ }^{59}$ Any Zanzibari could ostensibly wear any cloth, own any piece of porcelain, buy any clock, even though price and availability restricted many goods to relatively small groups. The weakening of patina in Zanzibar was the result of the BuSaidi destabilization of older political and social

\footnotetext{
57 Swahili was the language of communication in most environments throughout the nineteenth centurywith some exceptions, as among Indian businessmen, in state correspondence, or in some religious matters.

58 Grant McCracken fleshes out this distinction between systems of fashion and patina in Culture and Consumption, Bloomington: Indiana University Press, 1988: 16.

59 Glassman argues that the ever-wider distribution of previously "prestige" goods gave relatively poor people an opportunity to, "contest the precise meanings of what had once been exclusive markers of status and political power". Jonathon Glassman (1995) Feasts and Riot: Revelry, Rebellion and Popular Consciousness on the Swahili Coast, 1856-1888, Portsmouth, N.H.: Heinemann: 37.
} 
relationships. In Zanzibar City, BuSaidi political power was established not through violence against the local population, as it had been in Mombasa and Lamu, but through the delegitimization of an older political system represented by the Mwinyi Mkuu, the preOmani ruler of Zanzibar. Yet, in relegating the old political elite to the periphery of the commercial capital — and in the process successfully destabilizing older status symbols like the Mwinyi Mkuu's drums, horns, and other state regalia — the BuSaidis were faced with the project of establishing new symbols of authority. Seyyid Said turned to new consumer technologies that drew deeply on contemporaneous global material flows.

In the early nineteenth century, we can discern a marked attempt on Seyyid Said's part to create status codes that signified both his own abilities and those of his administration. In the $1840 \mathrm{~s}$ and 1850 s, he concentrated on a variety of objects to demonstrate his authority. In addition to decorating his palaces with clocks, mirrors, and all variety of imported furniture, he also purchased a 1100 ton frigate manufactured at Bombay and christened it "King of the World" (Shah Allum) ${ }^{60}$ Liberalizing much of Zanzibar's trade and concentrating on foreign objects to represent his authority - even sending ships to America, Europe, Bombay, and Mauritius to procure such goods - the new sultan released new consumer goods from their prior sumptuary restrictions. With the rapid dissolving of sumptuary regulations historically common in Swahili city-states, the centrality of consumerism to new social relations became a hallmark of Zanzibar's cosmopolitanism. The movement of population, free-floating cultural materials of distant origin, and the possibility for many to accumulate modest, if not significant, fortunes meant that forms of status presentation in the material realm were constantly open to challenge. Even a person of relatively meager means, like Rajab, could travel abroad and accumulate signs of distinction. In this conjuncture, social signs rendered by consumer objects were unstable; they were being continually negotiated in the public realm and in relationship to their own abundance. An example of this is the umbrella, once the preserve of the very wealthy, which became fashionable among those of meagre means in the 1870s. Likewise, the

\footnotetext{
60 See Ruete [Salme] (1993: passim). His sons would follow this tradition. Kirk to Gonne, 13 April 1869, and Letter from Suliman bin Ali Secretary to His Highness Seyd Majid Sultan of Zanzibar to Churchill, April 1869 , IOL L/P\&S/9/48.
} 
kizibao, or embroidered jacket of European broadcloth once popular among free men of means, later became one of the greatest investments for freedmen of lesser means. ${ }^{61}$

For all Zanzibaris, consumerism offered a technology that Nicholas Thomas has described as enabling people, "to act in novel ways, and have novel relations imposed upon them". 62 For the wealthy, fashion allowed for new extremes of material accumulation. One of Seyyid Said's sons, Khalid, indulged a predilection for everything French and assembled a collection of French objects that awed the visitor. Sayyida Salme wrote of his plantation, Marseille:

Except in the rooms set apart for prayer, the walls were all covered with mirrors...The floors of the rooms were paved with white and black marble slabs, the coolness of which cannot be estimated highly enough in the south. An artfully worked clock, from which upon the striking hours playing and dancing figures stepped out, round toilet-mirrors which reflected the forms in the most various distortions, large round quicksilver balls which can be seen here [in Germany, where she was writing her account] now and again in gardens, and other works of art made the palace Marseille into a real museum for the simple people who had been introduced only a little to civilization, especially for our relatives from Omân...63

This extreme of cultural domestication, of creating a museum of European curiosities, serves as a stark example of some elites' desire for association with specific symbols of elsewhere.

The apogee of fashion in Zanzibar also put constant pressure on elites to seek out new methods of distinction. As freed slaves and the plebeian population claimed forms of culturedness reminiscent of the wealthy, elites pursued new strategies for material

\footnotetext{
61 Laura Fair gives a particularly rich account of changes in fashion among non-elites in Pastimes and Politics in Zanzibar: Culture, Community and Identity in Post-Abolition Urban Zanzibar. (Athens, OH: Heinemann, 2001).

62 See A. Coombes \& A. Brah (2000) "Introduction: the conundrum of "mixing"”, and N. Thomas, "Technologies of conversion: cloth and Christianity in Polynesia," in A. Coombes \& A. Brah (eds.) Hybridity and its Discontents: Politics, Science, Culture, New York: Routledge: 1-16 and 198-215. The Comaroffs argue that Western clothes offered an "experimental language" for the creation of new identities, Comaroff (1997: vol. 2, 235).
}

63 Ruete [Salme] (1993: 259). 
definition. What I am suggesting here is something rather more complicated than the poor's aspiration to status, their appropriation of the symbols of the rich. What is equally important systemically is the wealthy's social desire to distinguish themselves from others as a group, a phenomenon that sometimes led to ludicrous extremes. ${ }^{64}$ This desire could address two intersecting goals: distinction from other wealthy people - a desire to "outdo" one's peers - and identification with a social group by publicly distinguishing oneself from people not in that group. Such acts of distinction were particularly concentrated on clothes but went beyond material signifiers. For example, around mid-century freed slaves appropriated the term waungwana - previously denoting historical prestige, genealogy, and wealth - for themselves. In response, by the end of the century the elite had championed a new word for themselves, a term that took on the nuances that uungwana had now lost: ustaarabu.

For the enslaved and poor of Zanzibari society, fashion could be both a powerful and an oppressive tool. It would become horribly oppressive to some since without resources a system of fashion could entirely foreclose social aspiration. With great premium on the symbolic qualities of clothing, the lack of resources to purchase certain kinds of dress consigned one to a kind of social alienation, acutely felt but unassailable without money. Yet, for much of the population, consumerism proved a mediating device in their social aspiration. Thus, while slave-owners attempted to remake slaves by giving them clothes after purchase, one of the primary aspirations of the enslaved was to re-clothe themselves and thereby lay claim to a new social citizenship. ${ }^{65}$ For slaves and poor free people of mainland birth, the acquisition of kanzus, fezes, and canes for men, and ukaya (muslin head covering), kisutu (English square cloth dyed in Bombay), and leso (large colorful cotton

\footnotetext{
64 Pierre Bourdieu (1984) Distinction: A Social Critique of the Judgment of Taste, Cambridge, MA: Harvard University Press. Bourdieu challenges the Veblenian notion of consumer demand as engaging in competition with one's neighbors, an attempt to either keep up with or outdo them. Certainly, there are elements of competitiveness in much inter- as well as intra-group consumer demand. Thus, we might think of demand as addressing inclusion, differentiation, and uniqueness alternately.

65 For the role of actual and metaphorical clothing in the discourses of slave making and unmaking see Jonathon Glassman (1991) "The Bondsman's New Clothes: The Contradictory Consciousness of Slave Resistance on the Swahili Coast," Journal of African History 32: 277-312 and Fair (2001). On the idea of consumption as constituting of "social citizenship", see Don Slater (1997) Consumer Culture and Modernity, Cambridge, UK: Polity Press: 4-5.
} 
handkerchiefs made in Manchester and sewn together in Zanzibar) for women became signs of an ability to ground oneself in the material relations of urban Zanzibar. Jewelry was so essential to appearances in Zanzibar that, according to Salme, even beggar-women were found in the streets "decked out" in various ornaments. ${ }^{66}$ Thus, in a very similar way to fashion among the wealthy, the consumption of "Swahili" clothes by the poor at once symbolized integration into a stratum of Zanzibari society and attempted distinction from others. It is this dual movement of claiming similarity to some and simultaneous difference from others that typified the fashion strategies of Zanzibaris of all socioeconomic categories. $^{67}$

The consumer objects individual Zanzibaris used to define themselves in many cases came to define Zanzibar as a whole. One object employed to represent the self that came into such common usage across socioeconomic lines that it became iconic of Zanzibar was the mirror. Zanzibar was the primary emporium for the whole of East Africa and thus the majority of consumer goods landed at Zanzibar found their way to the mainland. Mirrors, however, did not. Indicative of a longer trend, statistics on Zanzibari imports for 1861-1862 show that 80 percent of the total value of mirrors imported to Zanzibar stayed on the island, probably in the city itself. ${ }^{68}$ Mirrors are unique consumer goods because they give their owners the opportunity to symbolically reproduce themselves and their surroundings. Clocks placed between opposing mirrors, as Sayyida Salme described, created an infinity of clocks within a circumscribed space. Mirrors, particularly ones spanning the height of the room, but also the smaller looking glasses which lined the walls of the less wealthy, afforded self-indulgence, an opportunity to reproduce one's own image and that of one's

\footnotetext{
66 Ruete [Salme] (1993: 157).

67 On the Mrima, many Shirazi sought to affect an "Arab" identity in the latter nineteenth century in order to, as Glassman suggests, not only equate themselves with Omanis from overseas but also distinguish themselves from newcomers, Glassman (1995: 63).

68 Playfair, "Administration Report of the Zanzibar Political Agency, for the year ending 31 May, 1864," IOL L/P\&S/9/41. Of these, 62.5 percent were French imports, 31 percent were British re-exports from Bombay, and 6.5 percent were German (from Hamburg).
} 
possessions. ${ }^{69}$ Burton wrote that mirrors were cheap and abundant in late 1850s Zanzibar. One could find "looking glasses" in the market, and these as well as most goods could be obtained, according to an American resident, as cheap if not cheaper than in America or Europe. ${ }^{70}$ After the return of one of the sultan's ships from a trading venture, the prices could be driven down even further. For those who could afford larger mirrors, or a greater profusion of them, they became the foundation of interior design. In custom master Jairam Sewji's house mirrors "without number", as one visitor put it, hung on the walls. ${ }^{71}$ The value of mirrors was further heightened by their ability to project images of their owners even long after their death. The koma (Swahili: soul of a deceased person) of the last Mwinyi Mkuu, for example, remained in his house and could be seen reflected in the large mirrors of his reception hall. ${ }^{72}$

Like the Mwinyi Mkuu and Seyyid Said, Sultan Barghash used massive mirrors to reflect his image. In this way, mirrors became a statement of doubled individual and governmental power. Seated at the upper end of his receiving room, Barghash placed one large mirror directly behind him and hung on either side of it identical full-length oil paintings of himself. ${ }^{73}$ The profusion of mirrors reflected the sultan, his twin paintings, clocks and telescopes, crystal candelabras, gilt chairs and crimson seats, and, as Johnston remarked, "our persons on every side". ${ }^{74}$ In this hall of mirrors Barghash imposed images of himself

69 Baudrillard suggests that the advent of mirrors as central features of home decor in eighteenth- and nineteenth-century Europe reflects an expansion of consumers' consciousnesses, a new obsession with selfreplication. Jean Baudrillard (1996) The System of Objects, New York: Verso: 22-3.

70 Richard Burton (1860) The Lake Regions of Central Africa: A Picture Exploration, 2 vols, London: Longman: II, 400; Hines to Secretary of State, 25 October 1864, USCZ, Roll 2, Vol. 4-5; Colonel Sykes (1853) "Notes on the Possessions of the Imaum of Muskat, on the Climate and Productions of Zanzibar, and on the prospects of African Discovery from Mombas", Journal of the Royal Geographical Society 23: 107-8.

71 Edward Ropes (1973) The Zanzibar Letters of Edward D. Roeps, Jr., 1882-1892 (ed.) Norman Bennett, Boston: Boston University Press: 18.

72 H. Cotterill (ed.) (1879) Travels and Researches among the Lakes and Mountains of Eastern \& Central Africa. From the Journals of the Late J. Frederic Elton, London: John Murray: 66.

73 Barghash sat for several photographic portraits and, according to Johnston, he sent one of these to Paris with instructions for it to be enlarged, doubled, and converted from an image of him in sitting position to him standing. Harry Johnston (1886) The Kilima-njaro Expedition. A Record of Scientific Exploration in Eastern Equatorial Africa, London: Kegan Paul, Trench: 31-2.

74 Thomson (1881: 22-23). 
on others in infinite repetition, even when the sultan was not himself physically present. Representative of the new Zanzibari cultural ideology, where Barghash's father had once flanked his chair with paintings of sailing ships - symbolic of the global integration which he had helped to facilitate in Zanzibar-Barghash now hung portraits of himself next to mirrors that reflected him, his visitors, slaves, and courtiers endlessly. ${ }^{75}$

\section{Barghash and the Cosmopolitan Image}

Sultan Barghash's reign (1870-1888) marked the height of Zanzibar's prosperity and regional economic importance. It also saw the broad diffusion of a recognizable Zanzibari aesthetic across the coastal region and a greater imposition of the state on the daily lives of its subjects. ${ }^{76}$ Barghash undertook radical policies of remaking that included the installation of public clocks, a free public water system, electric lighting, a mint, the institution of a steamship line between Zanzibar and other Indian Ocean ports, the publication of treatises on Ibadhi law, ${ }^{77}$ the cultivation of new musical styles, investment in Zanzibar's transportation infrastructure, and an official visit to Europe as well as Mecca and Bombay. ${ }^{78}$ And decades before construction began on the Mombasa-Kampala railway, Barghash offered 500,000\$MT to any European company willing to construct a railroad from the Great Lakes to the coast. ${ }^{79}$ With the sole exception of the railroad, Barghash accomplished all of this with his own resources and of his own accord.

The aggressiveness with which Barghash pursued these ends radically altered Zanzibar. What is more, this all happened very fast. All of his major projects were completed

75 Hamerton quoted in John M. Gray (1962) History of Zanzibar, from the Middle Ages to 1856, London: Oxford University Press: 205; W. Cope Devereux (1869) A Cruise on the 'Gorgon'; or Eighteen Months on H.M.S. "Gorgon", Engaged in the Suppression of the Slave Trade on the East Coast of Africa, London: Bell \& Daldy: 296-7.

76 On the changing relation of the Barghash state to its subjects see Randall Pouwels (1979) "Islam and Islamic Leadership in the Coastal Communities of Eastern Africa, 1700 to 1914", Ph.D. diss., University of California, Los Angeles: part III.

77 According to R.S. O'Fahey (personal communication), Barghash acquired a printing press from Syrian Jesuits and ordered a 100 volume compendium of Ibadhi jurisprudence to be written up for publication. Johnston (1886: 333-4).

78 Kirk to Wedderburn, 1 January 1872 , IOL L/P\&S/9/49.

79 Henry M. Stanley (1878) Through the Dark Continent, vol. 1, New York: Harper Brothers. 
between the late 1870 s and the mid 1880 s. ${ }^{80}$ On his return to Zanzibar after only an eightyear absence, Henry Morton Stanley was astounded to find a telegraph station, new palace, clock towers, carriages, steamrollers, and streetlights. ${ }^{81}$ Barghash both imagined a new role for Zanzibar's government in local social services and encouraged the establishment of a new urban aesthetic. Perhaps more vigorously than before, during Barghash's reign Zanzibaris consciously remade the city in relation to diverse materials and changing imaginations of Europe, India, and other world regions.

Unlike his brothers, Barghash lived for an extended time outside of the Zanzibar-Muscat nexus before coming to power. After a failed coup in 1860, he was sent into exile in Bombay. His experiences in India deeply affected his outlook and, if the British Consuls in Zanzibar are to be believed, his general disposition. ${ }^{82}$ At the very least, he returned with a different strategy for dealing with Westerners. Whereas Barghash previously had been hostile to European influence, he was now willing to accept consular advice, though he did not follow the consuls blindly. ${ }^{83}$ Barghash's exile and subsequent visits to Bombay deeply influenced his ideas about civic services as well. Street lighting, an expanded police force, and even a light tram system were projects culled from his observations in Bombay. Almost immediately after his assumption of the sultancy, Barghash embarked on a concerted project of architectural innovation. One of his rural residences, Chukwani, built in the 1870 s and connected to the city by tram, showed particular British Indian influence in its wide verandah, massive columns, French doors, ornate overhangs, and bulbous colored glass lamps. Maruhubi palace, built a few years later, evidenced British Indian accents over an Omani-style structure with a perimeter wall inspired by park walls he had seen in Britain. ${ }^{84}$ Moreover, in the 1880 s all of his country homes were fitted with telephones.

80 Johnston (1886: 29).

81 Henry M. Stanley (1890) In Darkest Africa, London: Sampson Low.

82 Speer, Report on Zanzibar, 1862, USCZ, Roll 2, Vol. 4-5.

83 Playfair justified Barghash's banishment by arguing that he was "most intolerant of anything like civilizing influences and in his communications with Europeans he was habitually haughty even as to insolence". Playfair to Gonne, 19 April 1865, IOL L/P\&S/9/42.

84 Abdul Sheriff \& Javed Jafferji (1998) Zanzibar Town: an Architectural Exploration, Zanzibar: Gallery Publications: 76. 
Indicative of his aspirations for Zanzibar, and of both the wealth and commanding position the city now held in the region, Barghash constructed a tower near the harbor. Also Indian in inspiration, the structure was monumental. With eight terraced stories capped with a glass pyramid reminiscent of London's Crystal Palace, it towered over the city, forcing the attention of new arrivals. Fitted with electric lighting, it also functioned as a lighthouse. Even more symbolically, Barghash placed four massive clocks in the tower facing the city and harbor. The institution of state clocks complete with bells was a significant extension of the private amassing of clocks and watches that had begun in the 1830s. Assortments of wall-clocks were by this time a common feature in Zanzibari homes and mosques, and several large clocks had been installed in the steeple of the Anglican cathedral—gifts from Barghash to the church. But as signs of the state, the massive clocks set into the harbor tower were functionally unique. Whether or not people actually regulated their days by their measurements, the sultan's clocks on the waterfront made the timepiece a central material reference of the state and a public icon.

This domestication of the clock was not a conspicuous Europeanization of time, as the proliferation of public clocks on courthouses and in roundabouts would become in colonial capitals. Instead, the tower clocks reflected a self-conscious aesthetic that drew on symbols that were now fully domesticated. Therefore, the sultan's clock punctuated a longer iconographic history of the clock in the city as well as the state's desire to use it as a symbol. Soon after the tower's completion, Barghash ordered a clock from Germany that contained a mechanized soldier who would step forward, salute the sultan, and return to his abode at the top of every hour. ${ }^{85}$ Most telling of Zanzibar's particular domestication of global objects was the fact that the clocks were not set to European time-i.e., a twentyfour hour day beginning at midnight. Instead, the clocks were set to Zanzibari time: the day began with sunrise at one o'clock, or 7 a.m. in European time, and the clocks were readjusted every ten days to account for the changing length of the day. ${ }^{86}$ Barghash did not

\footnotetext{
85 (1885) "On the Track of the Germans in East Africa," The Pall Mall Gazette, 6182, vol. 41, 3 June.

86 W. Beehler (1885) The Cruise of the Brooklyn, Philadelphia: J.B. Lippincott: 174.
} 
Europeanize time in Zanzibar; rather, he adapted the European timepiece to Zanzibari perceptions of time.

Barghash's most impressive creolization of global symbols was the richly iconic Beit al Ajaib, or "House of Wonders", completed around 1883. The construction alone was unlike anything undertaken in nineteenth-century East Africa. Its outward appearance was, again, British Indian in inspiration: wide four-sided verandahs, French doors accented by lowhanging lamps, richly-worked wooden overhangs, a gleaming white finish, and massive carved doors of western Indian design embellished with a pair of lions on the half-circle lintel, at times buttressed by actual lions in nearby cages. ${ }^{87}$ Moreover, the external galleries were supported by roughly 140 cast iron pillars. ${ }^{88}$ Considered with other architectural and design innovations of the central city, the Beit al Ajaib, "a babble of [architectural] tongues", signified what S. Battle has called a "new self-consciousness" about the city's form-a self-consciousness about Zanzibar's relation to the world. Unlike other buildings of state in Zanzibar-including large storage facilities, the customs house, and accommodations for family members, slaves, and visitors - the Beit al Ajaib was a symbolic space, as evidenced by its narrow rooms but cavernous central auditorium. The auditorium, reaching up three stories from the floor to roof, was covered, unlike the courtyards of many Zanzibari houses, thus allowing free use of the space under any weather condition. Adding to its versatility, Barghash installed electric lighting in 1886. Barghash laid the Beit al Ajaib with the same French black and white marble that had come into common use by wealthy Zanzibaris and filled the building with large chandeliers. The reception room, according to Johnston, was "of Arab shape [rectangular] but later French decoration". It boasted "fine" Persian carpets, red velvet and gilt wood furniture, kitchen clocks, ormolu timepieces, aneroid barometers, thermometers, anemometers, telescopes, opera-glasses, musical-boxes, swords, spears, rifles, pistols, toys "of ingenious kinds",

\footnotetext{
87 According to oral tradition, the doors were carved by Indian artisans brought to Zanzibar specifically for this purpose. Interview with Muhammad Rashid, Beit al Ajaib, 5 August 2000; Sheriff \& Jafferji (1998: 52).

88 Battle has pithily suggested that Barghash's House of Wonders was, "an expression of domination, the city is the arena of display". S. Battle (1995) "The Old Dispensary: An Apogee of Zanzibari Architecture", in Abdul Sheriff (ed.) The History and Conservation of Zanzibar Stone Town, Athens: Ohio University Press: 94-96.
} 
photographic albums, portraits of world personalities, and sets of photographs of sites around the world. ${ }^{89}$

Johnston's account of the Beit al Ajaib suggests an aesthetic similar to the Crystal Palace, or London's Hall of the Great Exhibition. Barghash visited the Great Exhibition in 1875 and so it was no coincidence that he similarly arranged an endless variety of objects in his new palace. The House of Wonders was, like the Crystal Palace, ornamented with objects of manufacture representing new technologies, tools used for measurement and surveillance in particular..$^{90}$ The House of Wonders contained objects of display different from those in Seyyid Said's simply furnished palaces. But, like his father's residences, Barghash's House of Wonders domesticated new global objects in the service of the state. The House of Wonders was, in effect, a museum of the contemporary world, designed to equate the power of new consumer objects with the person of the monarch.

Inspired by the Beit al Ajaib, Taria Topan, an influential Ismaili businessman, customs master, and member of the sultan's cabinet, announced in 1887 his intent to construct the city's first public hospital. It would honor Queen Victoria's Golden Jubilee and for it, as well as for other services to the crown, he would be knighted. ${ }^{91}$ Built just north of the palace complex, the hospital, when paired with the House of Wonders, evidences the materialization of what has been termed the zeitgeist of the Barghash court: opulence, display, and a new aesthetic sensibility. ${ }^{92}$ Just as the Beit al Ajaib was no house, the dispensary was not designed like other hospitals. Battle's structural analysis suggests that it was a palace in its own right. The entire structure, inside and out, was replete with intricate

89 Johnston (1886: 31-32); John Willoughby (1889) East Africa and its Big Game: The Narrative of a Sporting Trip from Zanzibar to the Borders of the Masai, London: Longmans, Green \& Co.: 15-16.

90 On the sultan's visit to the Crystal Palace see the Times (London) 18 June 1875, as well as thirty other articles in the same paper covering his entire stay in England. See The New York Times, multiple articles from 10 June to 9 August 1875; L. Sabunji (1988) Tanzih al-absar wa-al-afkar fi rihlat Sultan Zanjabar, jama'ahu Zahir ibn Sa 'id, Muscat: Wizarat al-Turath al-Qawmi wa-al-Thaqafah; Kirk to Earl of Derby, 17 May 1875, IOL L/P\&S/9/51.

91 "Queen's Jubilee-Mr. T. Tohan [sic] of Zanzibar, Gift of an Hospital and £15,000 to Celebrate in, Zanzibar," Times (London), 2 March 1887, 11 col. F.

92 Battle (1995: 95). 
carvings and mouldings. Its balconies are the most richly worked in the city, and in the patients' wards the balconies feature decorated panels glazed with multicolored glass. A dining room on the second floor was fitted with a chandelier. ${ }^{93}$ The building was a structural creole, combining diverse Zanzibari standards like the courtyard, balcony, and the wikio, or bridges across the interior of the structure. Its walls were made of coral in a fashion like almost all contemporaneous structures on the East African coast, but they featured mouldings of a European neoclassical style. ${ }^{94}$ The hospital was a monument to both the cultural aesthetic of Topan and the localization of British Indian design as much as it was to any public good.

Similar to the contemporaneous houses of Muscat's commercial elite, Indian aesthetics in the built environment were everywhere evident in Barghash's Zanzibar. The increase in Indian immigration to the island and the accumulation of wealth by many Indian merchants during Zanzibar's commercial apogee spurred investment in the embellishment of older Zanzibari houses as well as the building of entirely new structures. Embellishment took the form of richly worked wooden balconies and other carved accents over the earlier OmaniEast African coastal architecture. Doors of Indian influence, sometimes even of Indian manufacture, were also common, recognizable by a rounded lintel intricately carved or, in the case of Gujarati styles, vertical and horizontal raised crossbeams. But just as Indian merchants were adding Bombay-inspired accents to Omani-Swahili creole structures, nonIndians were borrowing, as Barghash did, from the aesthetic vocabularies of Bombay, Gujarat, and Kutch. ${ }^{95}$ Tippu Tip, the famous Zanzibari trader who carved out a niche of political power for himself in Central Africa, installed an enormous Indian-inspired door on his house. The architecture of religion now also included an Anglican Cathedral and distinctly Indian-inspired structures, including Hindu temples (earlier banned in Zanzibar and Mombasa) as well as Khoja and Bohra mosques.

\footnotetext{
93 Battle (1995: 91).

94 Battle (1995: 96).

95 See in particular F. Siravo (1996) Zanzibar: A Plan for the Historic Stone Town, Zanzibar: The Gallery Publications.
} 
Barghash was a man infinitely curious of the world and even keener than his predecessors to collect pieces of diverse elsewheres. Like his father, he sent steamships on missions to England, Hamburg, Bombay, Muscat, Mauritius, and Jiddah. He regularly read Egyptian papers and informed the British Consul that there were Egyptian soldiers coming to "relieve" Livingstone long before the Consul had received the news. ${ }^{96}$ Barghash was also entirely cognizant of European representations of him. Johnston wrote that if Barghash was mentioned in the Times (London), his confidant Pera Dewji would bring him a copy of the article, circled in red chalk, for his perusal. ${ }^{97} \mathrm{He}$ was particularly curious about the European residents of Zanzibar, perhaps out of suspicion, perhaps because they were exceptionally exotic. With Dewji's assistance, Barghash collected information on all new European arrivals to the city. Barghash's "great pleasure", as Thomson explained, was "watching the ways of the foreigners from his palace window". Such "social investigations", Thomson wrote, were carried out with a powerful telescope. In this way, the sultan had become "acquainted with facts not intended for his eye. He has more than once revealed knowledge of a kind and extent", Thomson continued, "which has rather unpleasantly taken some Europeans by surprise". 98

His telescopic adventures, when combined with his travels in Europe, gave Barghash greater insight into the West than most Western residents possessed of East Africa. This is an important point because it reveals something of his cosmopolitan vision. Through his own travels and diverse means of assembling information about Westerners, Barghash certainly could have been inspired to embark on programs of state-sponsored social reform, the institution of a broader tax system, and any variety of post-Enlightenment projects common to the industrial European metropoles. But he did not pursue these Western courses. His projects suggest that he wished to shape a vision of global integration that was in dialectic with the West, as well as South Asia and the Middle East, but did not follow these in any formulaic way. Instead of instituting a policy of Westernization, Barghash invested in select services, such as the supply of drinking water, new roads, streetlights,

\footnotetext{
96 Frere to Granville, 14 January 1873, ZNA AA1/10.

97 Johnston (1886: 30).

98 Thomson (1881: 28).
} 
waste disposal, and free passage to those making the Hajj. Moreover, he invested little in mechanisms of direct social control, the expanded police force notwithstanding. He put most of his resources into (1) services broadly beneficial to Zanzibaris, and (2) the culturalsymbolic: a House of Wonders, electricity, public clocks, publications, and music. In short, his reformation was one intently focused on basic public services and public image. His cosmopolitanism did not aspire to replicate the West, but instead borrow from it to service his interests.

Barghash invested much in his state's public image. For example, his new military-which never saw an engagement - dressed in stark white and red European uniforms. Ropes, an American resident, wrote that two members of the guard dressed "in the most gorgeous uniforms I ever saw".99 The force was founded in 1877, given trousers, jackets, and Zanzibar's signature fez. ${ }^{100}$ Under the direction of a Briton, Lloyd Mathews, the sultan put his military on parade. They marched to the music of a brass band every Friday in front of the palace compound. The band was rather large, totaling thirty-five pieces, made up of mostly Goan musicians under the direction of a German conductor. ${ }^{101}$ Barghash composed his own anthem, usually called "God Save the Sultan" by Westerners - who described it as sounding "Egyptian" - and instructed the band to honor all visitors with their own national anthems. By 1882, Barghash was giving concerts every Wednesday evening. ${ }^{102}$ For the occasion he would set up chairs in the palace square where those who wished might, according to an English visitor, "listen to wonderfully well played operatic selections". ${ }^{103}$ Barghash also mixed Arabic music with European music. When he entertained American

\footnotetext{
99 Ropes (1973: 15); P. Charmetant (1882) D'Alger à Zanzibar, Paris: 131-37.

100 See Robert Lyne (1936) An Apostle of Empire, being the Life of Sir Lloyd William Matthews, London; Reginald Coupland (1939) The Exploitation of East Africa, 1856-1890, London: Faber \& Faber: 241-42; Ropes (1973: 15, fn. 51).

101 Ropes (1973: 15).

102 Willoughby (1889: 16); Johnston (1886: 31, 35); Ropes (1973: 10, 13, 31).

103 Thomson (1881: 26).
} 
visitors in 1884, he alternated between a band playing European operas and another performing "Arab airs". 104

Though many of the changes to the Zanzibari cityscape were monumental, the most dramatic symbol of Barghash's Zanzibar was an object that, by the 1880s, had become accessible to most Zanzibaris: the umbrella. As Jonathon Glassman and others have shown, on the nineteenth-century Swahili Coast umbrellas were particular symbols of the state and patrician identity. ${ }^{105}$ In early nineteenth-century Zanzibar, umbrellas of British, Indian, Chinese, and American manufacture were common accouterments of Asian businessmen. Wealthy women likewise carried them, but their use in Zanzibar seems to have been largely limited to these groups. ${ }^{106}$ By the 1870 s and 1880 s, umbrellas had been thoroughly appropriated by Zanzibaris of diverse backgrounds. Their ubiquity in Zanzibar evidences both the new consumerism and the greater democratization of some objects. Like mirrors, the vast majority of umbrellas imported into Zanzibar were purchased by Zanzibaris. As evidence of this great desire, between 1878 and 1882, Bombay exports of umbrellas to Zanzibar doubled, totaling nearly 27,000 a year. ${ }^{107}$ Zanzibar, in fact, became the single largest market for umbrellas exported from Bombay.

Umbrellas may have possessed some of the same sign values in New York, Bombay, Paris, and Zanzibar, but in Barghash's capital their use was not restricted to a specific class or group as it was in the West. There were myriad other goods, like carriages, silk cloth, and clocks, that created distance between the elites and the poor. Yet, marginal groups, including slaves, defied earlier conventions in Zanzibar by consuming umbrellas. In the process, umbrellas became associated with Zanzibari society broadly. Through their

\footnotetext{
104 Beehler (1885: 178-9).

105 Burton talked of coastal elites "priding themselves" on the public use of umbrellas. Burton (1860: vol.1, 34). See Glassman's discussion of the use of umbrellas at Saadani in Feasts and Riot, 157. This had been the case since at least the sixteenth century.

106 Burton (1872: vol. 1, 109); Burton (1860: vol. 1, 386-7).

107 “Annual Statement of Trade and Navigation of the Presidency of Bombay for the Year 1881-82," IOL $\mathrm{V} / 17 / 311$.
} 
appropriation, umbrellas were no longer simply elite objects, but now common symbols of cosmopolitan Zanzibar.

\section{Conclusion}

As a mode of social relation in nineteenth-century Zanzibar, consumerism articulated new senses of self that were inextricable from global flows. The conglomerations of clothes and interior decorations culled from global currents created a cultural code in Zanzibar greater than the sum of its parts. ${ }^{108}$ This code reflected a way of being in the world that was not only cognizant of trans-societal trends but made them relevant to the Zanzibari social environment. Much like Zanzibari sojourns in New York, Marseilles, Hamburg, and Bombay, the changing global visions of Zanzibaris challenged the uniqueness of Westerners' familiarity with "events and their consequences" all over the world by far exceeding the terms (to borrow Timothy Mitchell's phrase) of Westerner's projections of East African primitiveness. ${ }^{109}$

If we wish to dismantle the concepts of progression and development so essential to definitions of essential difference, we should yet be wary of the self-assured terms employed by Westerners in the nineteenth-century imperial moment. The notion of the "modern", for instance, is still accompanied by the spectre of imperial taxonomy and still discounts the possibilities and visions that exist alongside it. ${ }^{110}$ Thus, efforts to recover the modern for postcolonial ends should be vigilant not to gloss over the deep cultural and temporal implications of the modern, lest we forget the modernizing impulse to liberate others from their "traditions". Further, we should not underestimate the West's ideological

108 This notion of a cultural code "more than the sum of its parts" is borrowed from the Comaroffs" reflections (1997: vol. 2, 245).

109 “Introduction,” in Timothy Mitchell (ed.) (2000a) Questions of Modernity, Minneapolis: University of Minnesota Press: xv.

110 Robert Young has argued that the resurrection of another Victorian idea-hybridity-as a means of postcolonial critique has severe limitations since it necessarily conjoins divisive bio-categories to contemporary theory. Young writes: "[hybridity] may be used in different ways, given different inflections and apparently discrete references, but it always reiterates and reinforces the dynamics of the same conflictual economy whose tensions and divisions it re-enacts in its own antithetical structure". Robert Young (1995) Colonial Desire: Hybridity in Theory, Culture and Race, New York: Routledge: 27. 
investment in modernity as its historical success, now globalized. In looking out at the world in the nineteenth century, many Westerners saw aspects of their societies mirrored abroad, but they erred in translating these proximates as failed replications of the West. If anything should come of the recognition of the complex cultural domestications and global itineraries of Zanzibaris it should be that they trouble the self-perception of "moderns" as having unique acquaintance with "events and their consequences" around the world.

During the colonial era, Zanzibari temporal, social, and political imaginations would be infused with notions of the modern as the basic conceptual apparatuses brought to bear on everyday choices became increasingly influenced (through schools, courts, and political culture) by Western worldviews. ${ }^{111}$ However, even under colonialism Zanzibaris never merely mimicked Westerners, Indians, or Arabs. Zanzibari visions bore resemblances to those of people in other parts of the world but, like the image of the late Mwinyi Mkuu in the mirrors of his former palace, the residues of nineteenth-century cultural domestications contributed to a twentieth-century Zanzibari cosmopolitanism that reflected a complexity of global influences.

\section{Bibliography}

_ (1885) "On the Track of the Germans in East Africa," The Pall Mall Gazette 6182, vol. 413 June.

_ (2000) "Special Issue: Multiple Modernities", Daedalus 129 (1).

Aldrick, Judy (1997) “The Painted Plates of Zanzibar”, Kenya Past and Present 12: 26-8.

Alpers, Edward (1984) “'Ordinary Household Chores': Ritual and Power in a 19th-Century Swahili Women's Spirit Possession Cult”, International Journal of African Historical Studies 17 (4): 677-702.

Battle, S. (1995) “The Old Dispensary: An Apogee of Zanzibari Architecture”, in Abdul Sheriff (ed.) The History and Conservation of Zanzibar Stone Town, Athens: Ohio University Press: 94-96.

Baudrillard, Jean (1988) Jean Baudrillard: Selected Writings, (ed.) Mark Poster, Palo Alto: Stanford University Press.

111 As Jonathon Glassman demonstrates, imported concepts-much like the objects described above-were domesticated to speak to specific twentieth-century Zanzibari concerns. Jonathon Glassman (2004) "Slower than a Massacre: The Multiple Sources of Racial Thought in Colonial Africa", American Historical Review, 109 (3): 720-54. 
— (1996) The System of Objects, New York: Verso.

Beehler, W. (1885) The Cruise of the Brooklyn, Philadelphia: J.B. Lippincott, 1885.

Bennett, Norman (ed.) (1969) From Zanzibar to Ujiji, The Journal of Arthur W. Dodgshun, 1877-1879, Boston: Boston University.

Bourdieu, Pierre (1984) Distinction: A Social Critique of the Judgment of Taste, Cambridge, MA: Harvard University Press.

Breckenridge, Carol A. (ed.) (1995) Consuming Modernity: Public Culture in a South Asian World, Minneapolis: University of Minnesota Press.

— Pollock, S., Bhabha, Homi \& Chakrabarty, Dipesh (2002) “Cosmopolitanisms”, in Carol Breckenridge, S. Pollock, Homi Bhabha \& Dipesh Chakrabarty (eds.) Cosmopolitanism, Durham: Duke University Press.

Burton, Richard (1860) The Lake Regions of Central Africa: A Picture Exploration. 2 vols. London: Longman.

— (1872) Zanzibar: City, Island, and Coast, Vol. 1, London: Tinsley Brothers.

Comaroff, John (2002) "Governmentality, Materality, Legality, Modernity," in Jan Georg Deutsch, Peter Probst \& Heike Schmidt (eds.) African Modernities, Portsmouth: Heinemann.

— \& J. (1997) Of Revelation and Revolution, vol. 2, Chicago: University of Chicago Press.

Carson, C. (1994) "The Consumer Revolution in Colonial British America: Why Demand?" in C. Carson et al. (eds.) Of Consuming Interests: The Style of Life in the Eighteenth Century, Charlottesville: University of Virginia.

Charmetant, P. (1882) D’Alger à Zanzibar, Paris: Libr. Tardieu.

Clifford, James (1992) “Traveling Cultures," in Cultural Studies, ed. Lawrence Grossberg, Carrie Nelson, and Paula Treichler, 96-116. New York: Routledge, 114-5.

- (1997) Routes: Travel and Translation in the Late Twentieth Century, Cambridge: Harvard University Press.

Cooley, William (1852) Inner Africa Laid Open, in an attempt to trace the chief lines of communication across that continent south of the equator, London: Longman, Brown, Green, and Longmans.

Coombes, A. \& Brah, A. (2000) "Introduction: the conundrum of 'mixing", in A. Coombes \& A. Brah (eds.) Hybridity and its Discontents: Politics, Science, Culture, New York: Routledge: 1-16.

Cooper, Frederick \& Stoler, Laura (1997) Tensions of Empire: Colonial Cultures in a Bourgeois World, Berkeley: University of California Press.

Cotterill, H. (ed.) (1879) Travels and Researches among the Lakes and Mountains of Eastern \& Central Africa. From the Journals of the Late J. Frederic Elton, London: John Murray.

Coupland, Reginald (1939) The Exploitation of East Africa, 1856-1890, London: Faber \& 
Faber.

Deutsch, Jan Georg, Probst, Peter \& Schmidt, Heike (2002) "Cherished Visions and Entangled Meanings", in Jan Georg Deutsch, Peter Probst \& Heike Schmidt (eds.) African Modernities: Entangled Meanings in Current Debate, Portsmouth: Heinemann.

Devereux, W. Cope. (1869) A Cruise in the "Gorgon"; or Eighteen Months on H.M.S. "Gorgon," Engaged in the Suppression of the Slave Trade on the East Coast of Africa. London: Bell \& Daldy.

Dirlik, Arif (1999)“'Is there History After Eurocentrism: Globalism, Postcolonialism, and the Disavowal of History", Cultural Critique 42: 1-34.

Dussel, Enrique (1995) The Invention of the Americas: Eclipse of "the Other" and the Myth of Modernity, New York: Continuum.

(1997) The Underside of Modernity, (ed. \& trans.) E. Mendieta, New Jersey: Atlantic Highlands.

Eilts, H. (1962)“Ahmad bin Na'aman's Mission to the United States in 1840, The Voyage of Al-Sultanah to New York City”, Essex Institute Historical Collections 98 (AprilJuly): 218-77.

Erlmann, V. (1999) Music, Modernity, and the Global Imagination: South Africa and the West, New York: Oxford University Press.

Ewald, Janet (2000) "Crossers of the Sea: Slaves, Freedmen, and other Migrants in the Northwestern Indian Ocean, c. 1750-1914”, American Historical Review 105 (1): 6991.

Fair, Laura (2001) Pastimes and Politics in Zanzibar: Culture, Community and Identity in Post-Abolition Urban Zanzibar, Athens, OH: Heinemann.

Featherstone, M. et al. (eds.) (1995) Global Modernities, London: Sage.

French-Sheldon, M. (1892) Sultan to Sultan: Adventures among the Masai and other Tribes of East Africa, London: Saxon \& Co.

Friedman, Susan (2001) "Definitional Excursions: The Meanings of Modern/Modernity/Modernism”, Modernism/Modernity 8 (3): 493-513.

Glassman, Jonathon (1991) “The Bondsman's New Clothes: The Contradictory Consciousness of Slave Resistance on the Swahili Coast", Journal of African History 32: $277-312$.

(1995) Feasts and Riot: Revelry, Rebellion, and Popular Consciousness on the Swahili Coast, 1856-1888, Portsmouth, NH: Heinemann.

- (2004) "Slower than a Massacre: The Multiple Sources of Racial Thought in Colonial Africa", American Historical Review, 109 (3): 720-54.

Göle, N. (2000) “Snapshots of Islamic Modernities”, Public Culture 11 (1): 91-115.

Grant, James (1864) A Walk Across Africa, or Domestic Scenes from My Nile Journey, Edinburgh: William Blackwood \& Sons. 
Gray, John M. (1962) History of Zanzibar, from the Middle Ages to 1856, London: Oxford University Press.

Grossberg, Lawrence, Nelson, Cary \& Treichler, Paula A. (eds.) (1992) Cultural Studies, New York: Routledge.

Guillain, M. (1856) Documents sur l'histoire, la géographie et le commerce de l'Afrique Orientale, illustrated volume, Paris: Bertrand.

Hall, Stuart (1997) “The West and the Rest: Discourse and Power", in Stuart Hall et al. (eds.) Modernity: An Introduction to Modern Societies, Oxford: Blackwell.

— \& Sarat Maharaj (2001) Modernity and Difference, (ed.) Sarah Campbell \& Gilane Tawadros, London: Institute of International Visual Arts.

Hannerz, Ulf (1987) “The World in Creolization”, Africa 57: 546-59.

Höhnel, L. von (1894) Discovery of Lakes Rudolf and Stefanie, Vol. 1, London: Longmans, Green \& Co.

Humphery, Caroline (1995) "Creating a Culture of Disillusionment: Consumption in Moscow, a chronicle of changing times," in Worlds Apart: Modernity through the prism of the local, (ed.) Daniel Miller, New York: Routledge.

Jacob, Elizabeth \& Henry (2000) A Quaker Family in India and Zanzibar, 1863-1865, (ed.) Y. Bird, York: Ebor Press.

Jervis, John (1999) Transgressing the Modern: Explorations in the Western Experience of Otherness, Oxford: Blackwell.

Jiddawi, A. (1951) "Extracts from an Arab Account Book, 1840-1854,” Tanganyika Notes and Records 31: 27.

Johnston, Harry, (1886) The Kilima-njaro Expedition. A Record of Scientific Exploration in Eastern Equatorial Africa, London: Kegan Paul, Trench.

Kayamba, M. (1936) "The Story of Martin Kayamba Mdumi, M.B.E. of the Bondei Tribe," in Marjory Perham (ed.) Ten Africans, London: Faber and Faber. 173-99.

Lee, L. (1999) "Shanghai Modern: Reflections on Urban Culture in China in the 1930s", Public Culture 11 (1): 75-108.

Lyne, Robert (1936) An Apostle of Empire, being the Life of Sir Lloyd William Matthews, London: George Allen \& Unwin.

McClintock, Anne (1995) Imperial Leather: Race, Gender and Sexuality in the Colonial Conquest, New York: Routledge.

McCracken, Grant (1988) Culture and Consumption, Bloomington: Indiana University Press.

Mitchell, Timothy (ed.) (2000a)Questions of Modernity, Minneapolis: University of Minnesota Press.

_ (2000b) “The Stage of Modernity," in Timothy Mitchell (ed.) Questions of Modernity, Minneapolis: University of Minnesota Press. 
Osgood, J. (1854) Notes of Travel or Recollections, Salem: George Creamer.

Pickering, Charles (1876) The Races of Man and their Geographical Distribution (London: George Bell and Sons

Pouwels, Randall (1979) "Islam and Islamic Leadership in the Coastal Communities of Eastern Africa, 1700 to 1914”, Ph.D. diss., University of California, Los Angeles: part III.

Pratt, Mary Louise (1992) Imperial Eyes: Travel Writing and Transculturation, New York: Routledge.

Richards, T. (1990) The Commodity Culture of Victorian England: Advertising and Spectacle, 1851-1914, Palo Alto: Stanford University Press.

Ropes, Edward (1973) The Zanzibar Letters of Edward D. Ropes, Jr., 1882-1892, (ed.) Norman Bennett, Boston: Boston University Press.

Ross Browne, H. (1846, 1968) Etchings of a Whaling Cruise, reprint, Cambridge, MA: Belknap Press.

Ruete, Emily [Sayyida Salme] (1993) Memoirs of an Arabian Princess, in E. Van Donzel (ed.) An Arabian Princess between Two Worlds: Memoirs, Letters Home, Sequels to the Memoirs, Syrian Customs and Usages, New York: E.J. Brill.

Ruschenberger, W. A. (1839) Voyage Round the World; Including an Embassy to Muscat and Siam, in 1835, 1836, and 1837, Philadelphia, PA: Carey, Lea \& Blanchard.

Sabunji, L. (1988) Tanzih al-absar wa-al-afkar fi rihlat Sultan Zanjabar, jama'ahu Zahir ibn Sa id, Muscat: Wizarat al-Turath al-Qawmi wa-al-Thaqafah.

Said, Edward (1999) Covering Islam, New York: Vantage.

Sayyida Salme see Ruete, Emily

Sheriff, Abdul \& Jafferji, Javed (1998) Zanzibar Town: an Architectural Exploration, Zanzibar: Gallery Publications.

Siravo, F. (1996) Zanzibar: A Plan for the Historic Stone Town, Zanzibar: The Gallery Publications.

Slater, Don (1997) Consumer Culture and Modernity, Cambridge, UK: Polity Press.

Stanley, Henry M. (1878) Through the Dark Continent, vol. 1, New York: Harper Brothers.

— (1890) In Darkest Africa, London: Sampson Low.

Stearns, Peter (2001) Consumerism in World History: The Global Transformation of Desire, Routledge: New York.

Steere, Edward (1872) “On East African Tribes and Languages," Journal of the Anthropological Institute of Great Britain and Ireland 1: 143-54.

Subrahmanyam, Sanjay (1998) "Hearing Voices: Vignettes of Early Modernity in South Asia, 1400-1750”, Daedalus 127 (3): 75-104.

Sykes, Colonel (1853) "Notes on the Possessions of the Imaum of Muskat, on the Climate and Productions of Zanzibar, and on the prospects of African Discovery from 
Mombas," Journal of the Royal Geographical Society 23 (1853): 107-8.

Thomas, N. (2000) "Technologies of conversion: cloth and Christianity in Polynesia", in A. Coombes \& A. Brah (eds.) Hybridity and its Discontents: Politics, Science, Culture, New York: Routledge: 198-215.

Thomson, Joseph (1881) To the Central African Lakes and Back: The Narrative of the Royal Geographical Society's East Central African Expedition, 1878-80, London.

Tylor, Edward (1880, 1913) Anthropology: An Introduction to the Study of Man and Civilization, Reprint, London: D. Appleton and Co.

Wainwright, Jacob (1874) "Tagebuch von Jacob Wainwright über den Transport von Dr. Livingston's Leiche, 4 Mai 1873-18, Februar 1874”, Petermann's Mittheilungen 20: 187-93.

Wakefield, Rebecca (1879) Memoirs of Mrs. Rebecca Wakefield, Wife of the Rev. T. Wakefield, (ed.) R. Brewin, London: Hamilton, Adams, \& Co.: 112-13.

Weeks, Clelia (1868-69) “Zanzibar,” Harper's New Monthly Magazine 38 (Dec.-May): 313.

Williams, Raymond (1976) Keywords: A Vocabulary of Culture and Society, London: Fontana.

Willoughby, John (1889) East Africa and its Big Game: The Narrative of a Sporting Trip from Zanzibar to the Borders of the Masai, London: Longmans, Green \& Co.

Young, Robert (1995) Colonial Desire: Hybridity in Theory, Culture and Race, New York: Routledge. 